\title{
Postscript: Genuine Links and Useful Passports: Evaluating Strategic Citizenship
}

Rainer Bauböck, Journal of Ethnic and Migration Studies, online first; February 2018

Citizenship as an institution is in decline and yet demand for Western passports is rising steeply. The contributions in this special issue try to make sense of this apparent contradiction. As Christian Joppke has argued for some time (Joppke 2010), the separation of rights from citizenship status, easier access to naturalization, growing toleration of multiple citizenship and the establishment of a supranational citizenship of the European Union all point in the same direction. Citizenship is no longer a thick bundle of identity, rights, duties and political engagement that connects individuals to one particular nationstate. What emerges instead in Western democracies is "citizenship lite", a status that comes with "dutyfree rights" and that can be easily acquired, renounced and held simultaneously in several states.

Citizenship of this kind is for obvious reasons attractive to those whom the birthright lottery (Shachar 2009) has assigned to a country that offers them little in terms of opportunities and rights. The global hierarchy of citizenships can be overcome individually through upward mobility when individuals from second and third tier countries get access to the high-value citizenship of a first-tier state (Harpaz, in this volume). States can also spin money from that hierarchy by selling their passports to global investors and turning their citizenship thus into a commodity (Shachar and Hirschl 2007, Shachar and Bauböck 2014). As Peter Spiro points out in this contribution to this volume, these trends highlight the global inequality associated with citizenship rather than subverting it. If rich people in poor states or those with the right ancestry can acquire a second citizenship in a Western state, this breeds resentment and undermines efforts to flatten inequality within non-Western states. Spiro's answer to the inequality puzzles of dual citizenship is, however, that efforts to stem the tide are futile and it is therefore better to ride the waves. Plural nationality degrades citizenship and contributes to global inequality, but the best response might be a further diluting of the advantages conferred by citizenship itself.

Other contributions focus on the instrumental uses of citizenship in specific contexts. This shift of level reveals nuances that tend to get lost in sweeping discussions of global trends. Especially the three essays discussing dual citizenship policies in Central and Eastern Europe (Dumbrava, Pogonyi, Knott, in this volume) demonstrate to which extent citizenship remains a core issue of identity politics in this region. Both states and individuals engage in double games. For states, a strategic expansion of citizenship and voting rights to kin-minorities may be driven by a domestic electoral calculus but efforts of extraterritorial nation-building also reclaim symbolically lost territories and keep historic animosities between neighbours alive. Individuals who apply for an ancestry-based second citizenship in a kin state also seem to be mostly motivated instrumentally by the mobility value of a European passport but Pogonyi and Knott find in their fieldwork that many still feel that this document expresses a relevant ethic identity and that they reclaim a status that is legitimately theirs.

The Mexican case provides a contrasting example. Toleration of dual citizenship and the introduction of external voting rights seemed logical steps in a project of promoting a Mexican "global nation" that includes large diasporas in the US and Europe, but in Pablo Mateos' analysis these extraterritorial 
expansions of citizenship also subverted the dominant narrative of a homogenous mestizo nation. South Korea deviates more strongly from the global trend towards instrumentally motivated toleration of dual citizenship. Jaeeun Kim demonstrates how a Korean kin minority in China uses its ethnicity strategically for migration purposes, drawing on South Korean passports but also circumventing the non-responsive policies of the "homeland" towards its kin minority in China through a mobilization of Korean global ethnic networks. What is striking in all these case studies is that instrumental and identity values of citizenship seem to be closely linked rather than one depreciating the other.

Patrick Weil's contribution, finally, discusses another feature of liberal democratic citizenship that does not fit well with the notion of a global decline of citizenship through its predominantly strategic uses. As Weil explains, citizenship revocation by states was a much more sweeping power in the past than it is today. Even in the context of the "war against terrorism", Western states have found it hard to strip terrorist suspects of their citizenship. The UK with its historical legacy of imperial subjecthood provides the exception that confirms the rule. In France and the US efforts to enhance state powers of citizenship deprivation have been shipwrecked on the bedrocks of democratic constitutions that have over time strengthened the sovereignty of the citizen vis-a-vis the sovereignty of the state. Although the proliferation of multiple citizenship permits states to revoke citizenship without creating stateless persons, citizenship in liberal democracies seems to remain a strong and stable bond that can only very exceptionally be unilaterally severed by political authorities on grounds that doing so would be "conducive to the public good", as foreseen by the British Immigration, Asylum and Nationality Act of 2006.

In my short postscript to this special issue I will attempt to reconcile the apparently contradictory diagnoses about the future of citizenship by sketching a conceptual and theoretical framework for understanding the strategic value and uses of citizenship and how these impact on its decline or resilience as a core institution of democratic states and of the international state system.

\section{Athens, Rome and Westphalia}

In a classic essay, John Pocock stylized the contrast between Athenian and Roman conceptions of citizenship and argued that the latter was more in tune with contemporary liberal democracy than the former (Pocock 1995). Athenian citizenship was ethnically based and internally highly exclusionary. It required active participation in public deliberation and rotation in office based on lottery rather than election. In Aristotle's famous definition, Athenian citizens were those taking turns in ruling and being ruled (Aristotle 1962). By contrast, according to the Roman jurist Gaius, a citizen is a legal being, defined by his relations to things (i.e. a property owner) and his actions towards others under the law. He is "free to act by law [and] free to ask and expect the law's protection" (Pocock 1995: 37).

Roman citizenship was, however, in many ways not at all the precursor of today's republican and liberal models. While Athenian citizenship was conceptualized narrowly as a privilege for a small elite that ruled an ethnically homogenous polity, Roman citizenship expanded vastly beyond the boundaries of the city and became an instrument for pacifying and integrating the peripheries of the empire. Internally, it was much less egalitarian not only relative to Athenian citizenship but also when compared to the new 
republican ideals that emerged from the French and American revolutions. In Raymond Balot's interpretation, the inherently hierarchical and imperialistic character of Roman citizenship makes it as distant from membership status in liberal democracies as the direct democratic Athenian version (Balot 2017).

In order to understand the contemporary context of citizenship it is not sufficient to highlight continuities and contrasts with pre-modern eras. We need to introduce a third conception that is distinctly modern and attributes an entirely new role to citizenship as a mechanism for determining individual memberships in the international state system. This Westphalian conception differs fundamentally from both the democratic and insular Athenian version and the hierarchic and expansive Roman one. It is universal in aiming to attribute a citizenship status to each human being and it is egalitarian in relying on mutual recognition of citizenship statuses by equally sovereign states, but it does not entail any particular content either in terms of rights or political participation. In René de Groot's description, Westphalian citizenship, which lawyers call 'nationality', is 'an empty linkage concept' ["ein leerer Koppelungsbegriff"] (de Groot 1989), in Rogers Brubaker's words it is an "international filing system, a mechanism for allocating persons to states" (Brubaker 1992: 31).

Even this ultrathin conception of citizenship that is entirely neutral with regard to the nature of the political regime does, however, have a hard core. It is universally based on birthright acquisition, be it by descent or birth in the territory, and it obliges states to grant their citizens unconditional residence and to (re)admit them to their territory. Both of these features can be and have been not unfrequently breached, for example when states fail to issue birth certificates to newly born children or refuse to readmit their nationals when these are about to be deported from other states. Westphalian norms of mutual recognition are also violated when a regime deprives its citizens of their status in order to make them deportable or to prevent their return. Yet the contrast with ancient citizenship both of the Athenian and Roman type is still striking. For ancient city republics, sending bad or dangerous citizens into exile was an indispensable tool to keep a republic of citizens alive or to protect the imperial power from its internal enemies. In a Westphalian world, this practice becomes a dangerous breach of duties that states have towards each other since it threatens to undermine the function of citizenship as a mechanism for assigning populations to sovereign states. States have to identify their citizens and accept responsibility for them vis-à-vis other states.

Once we have clearly distinguished the three models, we can consider what they share pairwise with each other. Liberal democratic citizenship is articulated within the Westphalian framework. What is shares with Roman citizenship is a strong emphasis on individual rights conceived as legal relations that connect individuals horizontally in society and vertically to the rights-granting authorities. Yet the provision of rights need not always clearly distinguish between citizens and non-citizens. Whereas empires like Rome grant different sets of rights as privileges to specific groups in order to secure their loyalty to the centre of power, a liberal conception emphasizes instead the universality of rights and casts suspicion on distinctions between citizens and non-citizens residents in this regard.

Athenian and Westphalian conceptions of citizenship also have one feature in common that distinguishes them from the imperial Roman model: they are both strictly relational. Whatever rights 
and duties he or she may have, a citizen is first of all a member of a particular polity or a national of a particular state. In Hannah Arendt's words, " [a] citizen is by definition a citizen among citizens of a country among countries. His rights and duties must be defined and limited, not only by those of his fellow citizens, but also by the boundaries of a territory." (Arendt 1970: 81). This is not so in a Roman conception. Rome was not a country among countries but a city that claimed to rule the world as it was known then. What made St. Paul a Roman citizen was not his special relation to the city of Rome, but his legal status as a Jew born in the free city of Tarsus, which provided him with immunity from being put on trial outside the capital city of the Empire.

If the future of Western citizenship is Roman, as Christian Joppke claims it is, then this diagnosis does not so much point towards strategic uses of citizenship by states and individuals or towards the proliferation of multiple citizenships (which is actually at odds with the imperial core of a Roman conception); the Roman feature that seems to transform the Westphalian conception today is the attenuation of citizenship as a political and legal relation between individuals and states, i.e. the idea that citizenship must express in a 'genuine link'.

This idea is not a sentimental notion that tries to fill the empty relation with expectations about thick loyalties or identities; rather, it is a necessary condition for citizenship to serve its crucial Westphalian function of sorting individuals into states. As the International Court of Justice decided in its 1955 Nottebohm judgment that gave rise to the genuine link doctrine: A state must not bestow its nationality on an individual with whom it does not have any genuine link if this attribution is intended to subvert legitimate claims that another state has towards that individual. ${ }^{1}$

In normative debates, cosmopolitans often regret the fact that liberal democratic citizenship is caught in the Westphalian cage and regard this as a matter of global injustice. How can one possibly justify that people are born with citizenships that provide them with hugely unequal opportunities and degrees of freedom? But most cosmopolitan theorists are also committed to a democratic conception of citizenship. This should make them pause and reflect further on the affinity of democratic views with an Athenian model. Isn't a stable relation between a particular polity and its citizens a condition for their participation and representation in the government of that polity. To put it more bluntly: If everybody could vote in every election anywhere in the world, could we still regard the governments emerging from such elections as having a democratic mandate and being accountable to citizens?

Instead of exploring further what mixture between the three basic models is normatively the most attractive one, I want to consider first some objections against the view that the structure of Westphalian citizenship is profoundly relational and will return then to the topic of this special issue by asking how citizenship can be used instrumentally and non-instrumentally within the Westphalian relational structure and which instrumental uses might transform this structure.

\section{Birthright and multiple citizenship}

\footnotetext{
${ }^{1}$ Liechtenstein v. Guatemala [1955] ICJ.
} 
There are two objections against my claim that Westphalian citizenship needs to rely on genuine links. The first is that acquisition of citizenship through birthright is a matter of chance rather than an indicator for a genuine link. The second is that multiple citizenship is at odds with a condition of genuine link. The increasing toleration of dual nationality is then seen as a sign of the declining importance of genuine links. Let me consider each objection in turn.

In response to the first, one could point out that rules of birthright acquisition are often modified by conditions that do express a genuine link. All European countries that have some general ius soli rule now make acquisition based on birth in the territory conditional. Conditions are basically of three types: a parent must have a certain duration and legal status of residence before the birth of the child; or the child receives citizenship only after birth depending again on duration of residence or on residing in the country at the age of majority; or the child gets citizenship at birth only if a parent has also been born in the country ('double ius soli'). Each of these conditions aims at mitigating the chance effect of territorial birth through some retrospective or prospective indicator for a genuine link. The same can be said about countries that limit the transmission of citizenship iure sanguinis for children born abroad to the second generation.

However, there is no international legal norm that would prevent states from adopting unconditional ius soli or unlimited ius sanguinis. A significant number of states in North and South America stick to the former and an even larger number of states in the rest of the world to the latter. So how is this fact compatible with the notion that genuine links are necessary for a smooth functioning of citizenship in the Westphalian system? The answer to this question is that what counts as a genuine link does not only depend on the strength of the relation of an individual to a polity, it also depends on how that polity constructs its membership.

Let me illustrate this point with an analogy. Some Christian churches practice adult baptism because for them the church consists of those who have freely chosen their faith. Others baptize children because they believe that religious membership is a matter of descent that does not depend on active individual consent. Under neither view is it necessary that the individual has an intense and lasting social relation with the other members of the church before becoming a member herself. Under the first view the act of professing the faith is sufficient to establish a membership relation for the future; under the second, it is enough to be born into a family of current members.

No state adheres to an Anabaptist view of citizenship. Naturalisation is not the way how most people acquire their citizenship, it is just a corrective mechanism (similar to conversion) for those whose birthright citizenship no longer fits their current circumstances. No state adheres to a purely territorial view of citizenship either, according to which membership would be determined only by residence rather than birth or individual choice. ${ }^{2}$ Instead, states primarily attribute citizenship at birth and based

\footnotetext{
${ }^{2}$ Such a principle of ius domicilii would require systemic change at global level. If states adopted it individually while others stick to birthright and lifelong citizenship, the result would be statelessness for emigrants and conflict between states over forced naturalisations of immigrants.
} 
on circumstances of birth, which means that their conception of membership highlights birth itself as establishing a genuine link.

We can call this a constructivist interpretation of genuine link. No doubt, it often jars against a normative understanding of genuine link as referring to the density of social relations with other members. ${ }^{3}$ What gives the children born to 'birthright tourists' in the US a moral claim to citizenship if they grow up in another country? Why should Argentinian children with one Italian grandparent inherit Italian and EU citizenship while others born under similar circumstances don't? These are valid normative critiques, but in a way they only scratch the surface. The more fundamental question is why citizenship should be determined by circumstances of birth in the first place instead of just tracing peoples' social ties to particular countries through proxies such as duration of residence.

The answer lies not only in the need for simple and clear criteria on which states can easily keep records and that make populations legible in terms of their membership in the international state system. It lies also in the need for transgenerational continuity of those peoples on behalf of whom modern states claim to exercise legitimate power. Birthright rules for determining citizenship and the lifelong stickiness of that status that people carry with them when they move abroad divide human populations into stable peoples identified by their nationality. This division is structurally similar to that of land into state territories. And it equally serves the need for boundary maintenance in the international state system. In this system, what counts as a genuine link has a lot do with circumstances of birth and not only with the strength of social relations. ${ }^{4}$

At this point the second objection kicks in. The boundaries between peoples defined by their nationality is in one way not like that between territories. Land cannot belong to two states at the same time ${ }^{5}$ but people can. Multiple citizenship has been on the rise for several decades, ever more states tolerate it and ever more individuals are keen to pick up the offer. Does this trend erode the sorting function of Westphalian citizenship and is it at odds with its core norm that citizenship must express a genuine link?

From a Westphalian logic, it would be ideal if every human being were the citizen of one and only one state. From the last quarter of the $19^{\text {th }}$ century to the last quarter of the $20^{\text {th }}$ international lawyers have tried to approximate this ideal through international legal norms that aimed to prevent stateless and multiple citizenship, both of which they regarded as evils to be avoided (Harpaz and Mateos, this issue). The outcome of this process was, however, that states could largely agree on avoiding statelessness (although many of them still breach this norm) but not on any norm that would effectively prevent the proliferation of multiple nationality. The main reason for this is not an external one, let alone a postnational dynamic eroding the international state system; it is inherent in the basic features of this system: There is no global authority that sorts individuals into states; sovereign self-determination of states in matters of nationality law is as fundamental a principle as territorial sovereignty. States are

\footnotetext{
${ }^{3}$ See (Carens 2013) for a normative theory of citizenship based on social membership.

${ }^{4}$ Elsewhere I have argued that citizenship at local level should be based on residence rather than birthright because municipalities are nested within states and their relation to each other is not one of independence (Bauböck 2015).

${ }^{5}$ In this respect too the difference between modern states and empires is relevant. Empires had shifting and blurred frontiers, states have stable and bright borders.
} 
free to choose between ius sanguinis and ius soli and various mixtures between these principles, which inevitably generates multiple nationality when children of foreign nationals are born in a ius soli country. International legal norms against gender discrimination have inadvertently contributed to this effect by prohibiting forced changes of nationality imposed on foreign women marrying a citizen and by transmitting citizenship iure sanguinis to children from both the father's and the mother's side. States may require that immigrants renounce their foreign nationality upon naturalisation and may withdraw nationality from their citizens when these voluntarily acquire a foreign nationality, but they are free not to do so. ${ }^{6}$ And more and more states have come to realise that it is not in their interest to cut off their links to their citizens abroad or to deter immigrants from naturalising for the sake of preventing dual citizenship. Multiple citizenship can thus not be properly called an irregularity within the Westphalian system since it emerges inevitably from its basic principle of state sovereignty and since efforts to curb the phenomenon run up against widespread state interests. By contrast, stateless populations are an irregularity in a much more profound way. Being not recognised as a national by any state is not only a situation of extreme precariousness for the individuals concerned, having such people on their territory creates also a problem for states that cannot deport them since no other state is obliged to (re)admit them.

The normative shift towards toleration of multiple nationality is thus not so difficult to explain within Westphalian parameters. But doesn't multiple citizenship still undermine the notion that citizenship ought to be based on genuine links? This would be true if multiple citizenships were acquired by individual choice based on purely instrumental reasons or if states bestowed them on individuals on grounds that have nothing to with the reproduction of transgenerational people. As I will discuss in the final section, such practices exist, but they remain for the time being quite exceptional. Most dual citizens get their status because of some combination of birthright rules. As pointed out above, unconditional ius soli and unlimited ius sanguinis are over-inclusive from the perspective of moral claims to membership, but from the perspective of the states applying them they still express their national conception of genuine link and maintain their peoples across time.

For dual citizenships that result from incoming or outgoing naturalisations, the argument is much more straightforward. If states tolerate that their nationals acquire another citizenship and that foreign nationals can retain their previous one when they naturalise, then these attitudes express a positive commitment to maintaining links instead of cutting them as a condition for individuals' exercise of their human right to change their nationality. ${ }^{7}$

Finally, toleration of multiple nationality, which has steadily increased since the $1960 \mathrm{~s}^{8}$, is also a way in which states adapt to globalisation. In a world with high levels of international migration, shrinking distances and generally increased interdependence between states it is to be expected that more and more people will develop genuine links to two or more states. I conclude therefore that both from a

\footnotetext{
${ }^{6}$ See e.g. European Convention on Nationality, Art. 7

${ }^{7}$ See Universal Declaration of Human Rights, Article 15

${ }^{8}$ See https://macimide.maastrichtuniversity.nl/dual-cit-database/
} 
constructivist and form a normative perspective, birthright citizenship as well as multiple citizenship are compatible with a genuine link principle.

\section{The instrumental value and future of citizenship}

Let me now finally consider the distinction between instrumental and non-instrumental value of citizenship that is discussed by most contributions in this special issue. My first claim is that the two kinds of values generally do not conflict but complement each other. Where the relational structure remains strong, citizenship has both types of values for its holders. My second claim is that citizenship offered without a genuine link condition has only instrumental value. This is most obviously the case where states put their citizenship up for sale. My third claim is that a full marketization of citizenship would, however, depreciate also the instrumental value of citizenship because it would undermine the condition of reciprocal recognition of citizenships between states exercising territorial jurisdiction. Since I do not see such a development on the horizon, the question is whether such a hypothetical scenario should be regarded as utopian or dystopian and what membership arrangements could then replace a defunct state citizenship.

Citizenship acquired at birth or through naturalisation has instrumental value if it provides individuals with opportunities and rights that they would otherwise lack. It has non-instrumental value if they regard their citizenship as a relevant identity that they share with other citizens of that country. The two types of value vary rather independently from each other. People can feel a strong sense of belonging to a country that offers them few rights and opportunities while some citizens of wealthy democracies, whose citizenship has high instrumental value, use it to lead cosmopolitan lives with little attachment to the country that enables them to do so. Such discrepancies do not signal that there is a general conflict or trade-off. As long as the rules for attributing citizenship trace genuine links, people can enjoy both kinds of values depending on economic and political circumstances in the country and their individual attitudes and preferences.

The specific conditions for acquiring citizenship do, however, structure individual motivations for acquiring or renouncing citizenship (Bauböck 1994: 102-115). For example, if citizens enjoy considerably more rights than long-term residents, then immigrants will be more often instrumentally motivated to apply for naturalisation. By contrast, if the only additional benefit that citizenship provides them with is the right to vote, then those who still decide to naturalise will more often do so because they feel at home in the country. Naturalisation decisions are also motivated by the perceived relative instrumental and identity values of the citizenship of origin and that of the country of residence. If dual citizenship is not tolerated by either side, the net instrumental gain through naturalisation must be higher than the perceived identity loss resulting from being deprived of a citizenship of origin.

One interpretation of the "instrumental turn" hypothesis suggested in Joppke's essay (this issue) could be that the rules and conditions for acquiring citizenship are changing in such a way that instrumental motives tend to be incentivized and identity motives disincentivized. But this does not seem to be the case. The trends towards conditional ius soli, towards toleration of dual citizenship in naturalisations, towards quasi-citizenship status for long-term residents, and the supranational citizenship of the 
European Union all should have the opposite effect of weakening instrumental reasons for claiming another citizenship.

Another interpretation is more plausible. In a globalized world, more people are interested in the mobility value of citizenship. We can distinguish three broad categories. In nearly all contexts, immigrants are reluctant to give up their citizenship of origin - not merely because of 'sentimental' motives, but because dual citizenship provides them with free movement rights between their countries of origin and settlement. Secondly, as analysed in Harpaz' contribution (this issue), the citizens of second and third tier countries have very strong incentives to acquire the citizenship of a first tier state as an emigration ticket or as an insurance policy that allows them to stay. Finally, global elites are interested in collecting passports with high mobility value that widen the opportunity spaces within which they can sell their talents, invest their fortunes or minimize taxation of their income and wealth.

While the first of these three motives for instrumental uses of citizenship remains entirely compatible with a genuine link condition for acquisition and high identity value of both citizenships involved, this is much less so for the second and third categories. The question is then whether such purely strategic uses of citizenship will become ever more widespread and will eventually transform the relational structure of citizenship.

In spite of the impressive evidence provided by Yossi Harpaz for the quantitative salience of the phenonemon, I have some doubts that first tier countries are ready to match the huge demand for their citizenship in second tier countries with an ever-increasing supply. If they become concerned about second citizenships opening doors to unwanted immigrants, they will restrict their citizenship laws accordingly. It is true that visa waiver agreements and EU citizenship allow people who get access to an ancestry-based second passport to choose other destinations than the issuing states. Latin Americans seem to have used Italian passports mostly to move to the US and Spain rather than to Italy. But such schemes work well only as long as the destination states remain sufficiently open for these extraterritorially minted European migrants. Where the economic and political climate turns against further immigration, such channels are likely to be closed down by exercising political pressure on the citizenship-granting states to change their practices or by restricting free movement agreements with them.

The demand for multiple citizenships among the global elite is more likely to increase steadily and to be met with sufficient supply. There is a new global industry advising wealthy people where and how to buy golden residence permits or passports as well as governments how to increase their revenues and attract investment (Surak 2016). The impact of this phenomenon on the basic structure of Westphalian citizenship is still likely to be limited, not only because of the small numbers of people who can afford to pay and the small numbers of (mostly small) states with high-value citizenships that are interested in selling these. The more important reason is that this global market for citizenship is parasitic on the established relational structure and would collapse with this structure if it were fundamentally undermined. 
As pointed out above, the Westphalian citizenship relation is triangular: it involves the citizen, the state recognizing her as a citizen and all other states recognizing that citizenship. The most important instrumental value of citizenship lies in the international mobility rights that come with it. Imagine that the other EU member states had refused to recognise Maltese or Cypriot citizenship granted to investors or that states would suspend their visa waiver agreements with St. Kitts and Nevis for individuals buying a passport of this Caribbean island state. The global market value of these citizenships would drop very quickly.

But maybe we need to imagine a much more radical change in which the instrumental value of citizenship would no longer depend on state supply and recognition? What if there were an actually open global market in which states lost their monopoly on issuing citizenships? Such a thought experiment has been suggested by Matthew Webb. States would become like publicly owned shareholder companies. Individuals could then buy whatever citizenship they are interested in and can afford; they could also acquire multiple citizenships of the same state and could sell them freely to other individuals (Webb 2014). After an extended series of such transactions, the initial power of states to determine who their citizens are would vanish completely. The global distribution of citizenships would become a matter of individual choice and purchasing power. States might still continue to honour their promissory notes to admit anybody to their territory and to offer diplomatic protection to anybody abroad who holds their citizenship in order to prevent a decline in the market value of their citizenship.

The problem with this model is that states are not at all like shareholder companies that specialise in producing and selling bundles of rights and duties and that aim to maximize the value of their shares and profits from sales. They are institutions of coercive territorial government subjecting particular populations to their rule. Providing these populations with citizenship status and rights is what can make such rule legitimate. This presupposes that states retain the monopoly of issuing citizenship certificates and that their criteria when doing so serve the purpose of reproducing a stable transgenerational people linked to a particular territory. An open global market for citizenship would thus not so much enhance individuals' freedom of choice; it would radically change the nature of the object that they choose.

Webb's model is meant to test a normative argument about alternatives to a globally unjust principle of birthright citizenship; it is not an extrapolation of current trends towards instrumental uses of citizenship. Instead of discussing how to prepare for such an unlikely future, we need to consider whether we would find it desirable. One reason for regarding a radical marketization as dystopian has to do with the Athenian legacy of liberal democratic citizenship. The legitimacy of coercive government depends on the political component of citizenship more than on the provision of civil liberties and social rights. Citizens must see governments as being their governments - as being elected by them, representing them and being accountable to them. This relation of representation and accountability can only be stable if the composition of the citizenry is shielded from excesses of strategic choice by both governments and individuals. The people cannot elect their governments if governments can elect their own people. And the government cannot represent a people if individuals can freely choose what people they want to be members of. The Westphalian need for stable division of humankind into distinct state peoples and the Athenian ideal of democratic self-government converge in their need for genuine links between citizens and states that constrain strategic choices. 


\section{Conclusions}

I have argued in this postscript that we need to understand modern citizenship as being shaped not only by the two ancient legacies of Athenian democracy and Roman law, but also by the modern Westphalian state system in which citizenship has acquired a new role as a mechanism for sorting humanity into distinct state peoples. I have then resolved the puzzle that birthright citizenship seems to be at odds with a Westphalian norm that citizenship ought to be based on genuine links by proposing a constructivist interpretation of this principle that gives equal weight to the strength of individual ties to a particular polity and to the conditions under which this polity can reproduce itself over time. A second puzzle is how the proliferation and increasing toleration of multiple citizenship can be reconciled with the presumptive need for genuine links. My suggestion was that from the individual migrant's perspective there is nothing strange about having multiple but still genuine links to several states, while state sovereignty in matters of nationality and state interests in providing both emigrants and immigrants with access to citizenship make the toleration of multiple citizenship an unavoidable feature of the Westphalian system rather than an irregularity.

In the concluding section I have argued that citizenship based on genuine links has normally both instrumental and identity value for those who possess it, but that the rules for acquisition and renunciation may structure individuals' choices through incentives that foreground either the instrumental or non-instrumental value of a particular citizenship. Contrary to many scholars' views liberal trends in citizenship reform generally weaken instrumental incentives. These effects are, however, counterbalanced by enhanced opportunities and interests in mobility rights that strengthen instrumental interests in multiple citizenship among immigrants, among populations in less developed countries and among highly skilled and wealthy elites. I remain sceptical about the transformative impact of these trends and conclude that a radical marketization of citizenship would also be normatively undesirable from a democratic perspective.

Citizenship is hugely important for people's autonomy and chances to lead a good life as well as for governments' capacity and legitimacy to rule them. In both respects different citizenships have always proved to be unequal. Such inequalities create incentives for strategic choices of citizenship by individuals while the norm of national self-determination allows for strategic abuses by governments. This has been the case in Athens, in Rome and in the modern Westphalian state system. Globalisation has strengthened the incentives for strategic uses and governments have responded by providing more opportunities. The extent to which citizenship can adapt, will lose weight or prove resilient remains to be seen. The analyses collected in this volume provide no single answer but they help us to understand the important challenges and changes that lie ahead.

\section{References}

Arendt, Hannah 1970. Men in Dark Times. San Diego: Harvest Books.

Aristotle. 1962. The Politics. Transl: T.A.Sinclair, revised and commentary: J. Saunders ed. London Penguin. 
Balot, Raymond. 2017. "Revisiting the Classical Ideal of Citizenship: A Dialectical Approach." In The Oxford Handbook of Citizenship, edited by Ayelet Shachar, Rainer Bauböck, Irene Bloemraad and Maarten Vink. Oxford: Oxford University Press.

Bauböck, Rainer. 1994. Transnational Citizenship. Membership and Rights in International Migration. Aldershot, UK: Edward Elgar.

Bauböck, Rainer. 2015. "Morphing the Demos into the right shape. Normative principles for enfranchising resident aliens and expatriate citizens." Democratization 22 (5):820-839.

Brubaker, Rogers W. . 1992. Citizenship and Nationhood in France and Germany. Cambridge, Ma: Harvard University Press.

Carens, Joseph H. 2013. The Ethics of Immigration. Oxford: Oxford University Press.

de Groot, Gerard-René 1989. Staatsangehörigkeitsrecht im Wandel. Eine rechtsvergleichende Studie über Erwerbs- und Verlustgründe der Staatsangehörigkeit. Köln: Carl Heymans Verlag.

Dumbrava, Costica. Forthcoming. The Ethno-Demographic Impact of Co-Ethnic Citizenship in Central and Eastern Europe. Forthcoming in Journal of Ethnic and Migration Studies.

Harpaz, Yossi. Forthcoming. Compensatory Citizenship: Dual Nationality as a Strategy of Global Upward Mobility. Forthcoming in Journal of Ethnic and Migration Studies.

Harpaz, Yossi and Pablo Mateos. Forthcoming. Introduction: Strategic Citizenship: Negotiating Membership in the Age of Dual Nationality. Forthcoming in Journal of Ethnic and Migration Studies.

Joppke, Christian. 2010. "The Inevitable Lightening of Citizenship." European Journal of Sociology/Archives européennes de sociologie 51 (1):9-32.

Joppke, Christian. Forthcoming. The Instrumental Turn of Citizenship. Forthcoming in Journal of Ethnic and Migration Studies.

Kim, Jaeeun. Forthcoming. Ethnic Capital and Flexible Citizenship in Unfavorable Legal Contexts: Stepwise Migration of the Korean Chinese Within and Beyond Northeast Asia. Forthcoming in Journal of Ethnic and Migration Studies.

Knott, Eleanor. Forthcoming. Strategy, Identity or Legitimacy? Analysing Engagement with Dual Citizenship from the Bottom-Up. Forthcoming in Journal of Ethnic and Migration Studies.

Mateos, Pablo. Forthcoming. The Mestizo Nation Unbound: Dual citizenship of Euro-Mexicans and USMexicans. Forthcoming in Journal of Ethnic and Migration Studies.

Pocock, J. G. A. 1995. "The Ideal of Citizenship since Classical Times (1992) reprinted in." In Theorizing Citizenship, edited by R. Beiner, 29-52. New York: State University of New York Press.

Pogonyi, Szabolcs. Forthcoming. The Passport as Means of Identity management: The Uses of Hungarian Extraterritorial Citizenship. Forthcoming in Journal of Ethnic and Migration Studies.

Shachar, Ayelet. 2009. The Birthright Lottery. Citizenship and Global Inequality. Cambridge, MA: Harvard University Press.

Shachar, Ayelet, and Rainer Bauböck, eds. 2014. Should Citizenship be for Sale? Vol. 1, EUI Working Paper RSCAS. Florence: Robert Schuman Centre for Advanced Studies, European University Institute.

Shachar, Ayelet, and Ran Hirschl. 2007. "Citizenship as Inherited Property." Political Theory 35 (3):253287.

Spiro, Peter J. Forthcoming. The Equality Puzzles of Plural Citizenship. Forthcoming in Journal of Ethnic and Migration Studies.

Surak, Kristin. 2016. "Our Citizenship is Expensive!" London Review of Books. 38(18): 39-40.

Webb, Matthew. 2014. "Citizenship for Sale. National Rights as Transferable Goods." 4th Annual Conference on Political Science, Sociology and International Relations (PSSIR 2014). doi: 10.5176/2251-2403_PSSIR14.04.

Weil, Patrick. Forthcoming. Denaturalization, Denationalization and Dual Citizenship in Comparative Perspectives. Forthcoming in Journal of Ethnic and Migration Studies. 